\title{
ANALISIS FAKTOR-FAKTOR YANG MEMPENGARUHI PENGHIMPUNAN DEPOSITO BERJANGKA PADA BANK UMUM DI INDONESIA
}

\author{
Moehammad Budi Widajanto \\ Sekolah Tinggi Ilmu Ekonomi "Urip Sumoharjo" Surabaya \\ budiwidajanto1973@gmail.com
}

\begin{abstract}
ABSTRAK
Penelitian ini bertujuan untuk mengetahui apakah faktor-faktor pendapatan nasional, tingkat bunga deposito, tingkat inflasi, nilai tukar US dollar terhadap rupiah, dan Indeks Harga Saham Gabungan (IHSG) mempunyai pengaruh signifikan terhadap penghimpunan deposito berjangka pada bank umum di Indonesia. Populasi dalam penelitian ini adalah bank umum di Indonesia, dan data penelitian diambil per triwulan selama periode triwulan I 2006 - triwulan II 2013. Analisis data yang digunakan adalah regresi linear berganda dengan uji $F$ dan uji t untuk menguji hipotesis pengaruh simultan dan parsial. Berdasarkan hasil penelitian diketahui bahwa pendapatan nasional, tingkat bunga deposito, tingkat inflasi, nilai tukar US dollar terhadap rupiah, dan Indeks Harga Saham Gabungan secara simultan berpengaruh signifikan terhadap penghimpunan deposito berjangka pada bank umum di Indonesia. Berdasarkan hasil pengujian parsial diketahui bahwa pendapatan nasional, tingkat bunga deposito, nilai tukar US dollar terhadap rupiah, dan Indeks Harga Saham Gabungan secara parsial berpengaruh signifikan terhadap penghimpunan deposito berjangka pada bank umum di Indonesia. Namun tingkat inflasi secara parsial tidak berpengaruh signifikan terhadap penghimpunan deposito berjangka pada bank umum di Indonesia. Berdasarkan hasil penelitian diketahui pula bahwa dari kelima variabel bebas yang diteliti, pendapatan nasional memiliki pengaruh dominan terhadap penghimpunan deposito berjangka pada bank umum di Indonesia.
\end{abstract}

Kata Kunci : pendapatan nasional, tingkat bunga deposito, tingkat inflasi, nilai tukar US dollar terhadap rupiah, dan Indeks Harga Saham Gabungan, deposito berjangka

\section{PENDAHULUAN}

Seperti negara berkembang pada umumnya, Indonesia mengalami kekurangan dana domestik guna membiayai pembangunan. Sehubungan dengan hal itu, Indonesia perlu mendatangkan modal asing untuk menutup kekurangan tabungan domestik, untuk keperluan investasi agar target pertumbuhan ekonomi yang cukup tinggi dapat dicapai.

Salah satu jenis modal asing yang masuk ke Indonesia adalah berupa pinjaman luar negeri baik yang mengalir ke sektor pemerintah maupun swasta nasional. Penggunaan pinjaman luar negeri mempunyai fungsi sebagai pelengkap dana domestik yang masih belum memadai untuk membiayai 
seluruh proses pembangunan di Indonesia. Namun demikian, penggunaan pinjaman luar negeri yang semakin besar porsinya dalam pembiayaan pembangunan, telah menciptakan ketergantungan terhadap negaranegara/lembaga donor, menimbulkan beban hutang yang makin berat, dan turut andil pada terjadinya krisis nilai tukar dan krisis ekonomi di Indonesia pada tahun 1997.

Usaha mobilisasi dana domestik merupakan masalah yang sangat penting, agar penggunaan modal asing khususnya pinjaman luar negeri dapat dikurangi. Mobilisasi dana masyarakat merupakan salah satu kegiatan di sektor perbankan, yaitu suatu usaha untuk menghimpun dana masyarakat untuk disalurkan di sektor riil.

Salah satu institusi yang mempunyai peranan penting dalam menghimpun dana masyarakat adalah lembaga perbankan. Upaya untuk menghimpun dana masyarakat pada bank yang berupa simpanan giro, deposito, dan tabungan, perlu lebih diintensifkan agar semakin besar jumlah dana masyarakat yang tersedia bagi kegiatan investasi pada berbagai bidang kegiatan ekonomi.
Dari ketiga jenis simpanan masyarakat pada bank, yang paling besar porsinya adalah deposito berjangka. Proporsi yang dominan dari deposito berjangka dalam penghimpunan dana masyarakat pada bank umum di Indonesia terjadi sejak tahun 1983 yaitu sebesar 47,3\% dari total dana masyarakat yang dihimpun oleh bank umum, dan hal ini berlanjut hingga saat ini.

Berdasarkan kajian literatur yang ada, peneliti mengemukakan adanya beberapa faktor yang mempengaruhi penghimpunan deposito berjangka masyarakat oleh bank umum di Indonesia, yaitu pendapatan nasional, tingkat bunga deposito, tingkat inflasi, nilai tukar US dollar terhadap rupiah, dan Indeks Harga Saham Gabungan (IHSG).

\subsection{Tujuan Penelitian}

Tujuan dari penelitian ini adalah:

1. Untuk mengetahui apakah faktorfaktor pendapatan nasional, tingkat bunga deposito, tingkat inflasi, nilai tukar US dollar terhadap rupiah, dan Indeks Harga Saham Gabungan (IHSG) secara simultan berpengaruh signifikan terhadap penghimpunan deposito berjangka pada bank umum di Indonesia. 
2. Untuk mengetahui apakah faktorfaktor pendapatan nasional, tingkat bunga deposito, tingkat inflasi, nilai tukar US dollar terhadap rupiah, dan Indeks Harga Saham Gabungan (IHSG) secara parsial berpengaruh signifikan terhadap penghimpunan deposito berjangka pada bank umum di Indonesia.

3. Untuk mengetahui manakah dari kelima faktor tersebut, manakah yang mempunyai pengaruh dominan terhadap penghimpunan deposito berjangka pada bank umum di Indonesia.

\section{TINJAUAN PUSTAKA}

\subsection{Hubungan Pendapatan Nasional dan Simpanan}

Untuk menjelaskan hubungan antara pendapatan dan simpanan (saving), bisa digunakan teori "absolute income hypothesis". Teori ini merupakan hasil dari pemikiran Keynes yang menjelaskan tentang hubungan antara pendapatan dengan konsumsi dan simpanan. Oleh karena simpanan merupakan bagian pendapatan yang tidak dikonsumsikan, maka menurut Keynes simpanan (saving) merupakan fungsi dari pendapatan. (Fry, 2006:5)
Menurut Keynes, setiap proses produksi dalam perekonomian akan mempunyai akibat ganda. Di satu pihak proses produksi akan menghasilkan barang dan jasa, sedangkan di pihak lain akan memberikan imbalan kepada faktorfaktor produksi yang terlibat didalamnya. Imbalan tersebut dapat berupa upah/gaji bagi para tenaga kerja, bunga bagi pemilik modal, sewa bagi pemilik tanah dan sumber daya alam lainnya, dan dapat berupa keuntungan (profit) bagi para pengusaha. Dengan kata lain, proses produksi menghasilkan pendapatan dalam masyarakat, yaitu bagi sektor rumah tangga. (Boediono, 2005:36)

Menurut Keynes, tidak semua dari pendapatan yang diterima seseorang akan digunakan untuk konsumsi, melainkan sebagian akan disimpan sebagai simpanan (saving). (Boediono, 2005:37). Lebih jauh dikatakan bahwa perilaku konsumsi dan menyimpan dari seseorang sangat dipengaruhi oleh pendapatannya. Suatu kenaikan dalam pendapatan akan meningkatkan konsumsi dan simpanan, tetapi tidak sebesar kenaikan dari tingkat pendapatannya. Hubungan antara pendapatan, konsumsi, dan simpanan dapat dituliskan dalam bentuk persamaan berikut:(Reksoprayitno, 2006:48) 
$\mathrm{C}=\mathrm{a}+\mathrm{b} \mathrm{Y}$

$S=-a+(1-b) Y$

Dimana :

$\mathrm{C}=$ Konsumsi agregat

$\mathrm{S}=$ Simpanan agregat

$\mathrm{a}=$ Konsumsi otonom

$\mathrm{Y}=$ Pendapatan agregat

$\mathrm{b}=$ Marginal Propensity to Consume

(MPC)

$(1-b)=$ Marginal Propensity to Save (MPS

Dari kedua persamaan di atas kita dapat melihat bahwa terdapat hubungan positif antara pendapatan dengan konsumsi dan simpanan (saving). Konsumsi otonom (autonomus consumption) adalah besarnya konsumsi pada saat seseorang tidak memperoleh penghasilan, hal ini terjadi karena orang tersebut harus melakukan konsumsi untuk memenuhi kebutuhan hidupnya walaupun orang tersebut tidak mempunyai penghasilan. Untuk memenuhi kebutuhan konsumsinya, seseorang dapat melakukan pinjaman sehingga besarnya simpanan adalah negatif (-a).

Besarnya konsumsi dan tabungan seseorang tergantung pada besarnya kecenderungan marginal untuk melakukan konsumsi (marginal propensity to consume/MPC) dan kecenderungan marjinal untuk menyimpan (marginal propensity to save). MPC adalah besarnya bagian dari tambahan pendapatan yang akan dipakai untuk konsumsi, sedangkan MPS adalah besarnya bagian dari tambahan pendapatan yang tidak dibelanjakan melainkan disimpan. (Reksoprayitno, 2006:49)

\subsection{Hubungan Tingkat Bunga dan} Simpanan

Hubungan antara tingkat bunga dan simpanan dapat dijelaskan dengan teori loanable funds, yaitu merupakan sisi supply dari loanable funds. Sisi supply dari loanable funds menerangkan hubungan antara tingkat bunga dan simpanan, dimana hubungan kedua variabel tersebut bersifat positif. Semakin besar tingkat bunga akan meningkatkan kesediaan masyarakat untuk menyimpan dananya pada lembaga perbankan, sehingga jumlah simpanan masyarakat pada lembaga perbankan akan naik.

Seperti yang dikatakan oleh Rose, et al. (2007:69) bahwa "As interest rate rise, individuals may desire to postpone current consumption for higher future consumption because they are earnings relatively high rates of interest. This 
substitution effect is associated with a positive slope for supply of savings curve.

Dari pendapat yang dikemukakan di atas dapat diuraikan bahwa dengan naiknya tingkat bunga simpanan, masyarakat akan menunda penggunaan kelebihan dananya untuk konsumsi sekarang (di luar kebutuhan hidup seharihari) dengan harapan akan memperoleh pendapatan untuk konsumsi yang lebih banyak di masa mendatang. Dengan begitu maka masyarakat akan menginvestasikan kelebihan dana yang dipunyainya pada bank-bank yang ada. Hal ini terjadi karena masyarakat akan memperoleh pendapatan yang lebih banyak dengan naiknya tingkat bunga tersebut.

\subsection{Hubungan Inflasi dan Simpanan}

Naiknya laju inflasi, sementara tingkat bunga simpanan di bank tetap, akan mengakibatkan turunnya tingkat bunga riil perbankan. Kondisi ini akan mempengaruhi perilaku penyimpan, dimana para penyimpan akan cenderung mengurangi simpanannya di bank dan digunakan untuk melakukan pembelian barang dan jasa atau diinvestasikan dalam bentuk lain. Sehingga meningkatnya laju inflasi, dengan tidak diikuti kenaikan tingkat bunga, akan dapat mengakibatkan menurunnya simpanan masyarakat pada lembaga perbankan.

Kenaikan harga (inflasi) tidak lain adalah suatu "pajak" atas saldo kas yang dipegang masyarakat karena uang makin tidak berharga. Orang-orang berusaha menghindari "pajak" ini dengan jalan mengubah saldo kasnya menjadi barang. (Boediono, 2005:162)

\subsection{Hubungan Nilai Tukar terhadap} Simpanan Masyarakat di Bank Umum

Nilai tukar (exchange rate) atau kurs adalah harga atau nilai mata uang suatu negara dinyatakan dalam nilai mata uang negara lain. Kurs valuta asing juga didefinisikan sebagai jumlah uang domestik yang dibutuhkan, yaitu banyaknya rupiah yang dibutuhkan untuk memperoleh satu unit mata uang asing (Sukirno, 2012:397).

Salah satu motif utama seseorang menyimpan dana di bank adalah untuk memperoleh return berupa bunga. Apabila simpanan tersebut dalam bentuk deposito rupiah di bank umum, maka besarnya return itu selain dipengaruhi oleh tingkat bunga, juga dipengaruhi oleh nilai tukar US Dollar terhadap rupiah.

Jika nilai tukar US Dollar terhadap rupiah naik, maka simpanan deposito rupiah cenderung merugikan penabung 
(deposan), karena akan mengurangi return yang diterima oleh penabung. Hal ini akan membuat penabung mengalihkan simpanan depositonya dari rupiah ke dalam deposito US dollar, sehingga jumlah simpanan deposito rupiah akan cenderung menurun. Sebaliknya, jika nilai tukar US Dollar terhadap rupiah turun, maka penabung akan mengalihkan simpanan depositonya dari bentuk US Dollar menjadi deposito rupiah, sehingga jumlah simpanan deposito rupiah masyarakat di bank umum akan naik.

\subsection{Hubungan Indeks Harga}

Saham Gabungan terhadap Simpanan Masyarakat di Bank Umum

Menanamkan dana dalam bentuk simpanan deposito di bank merupakan salah satu alternatif yang dilakukan oleh seseorang untuk memperoleh return dalam jangka waktu tertentu. Selain menanamkan dana dalam bentuk simpanan deposito di bank, seorang pemilik dana dapat mencari alternatif lain dalam menanamkan dananya yaitu dalam bentuk pembelian saham.

Pemilik dana akan mempertimbangkan mana yang lebih menguntungkan dalam arti memberikan return yang lebih besar antara menanam dana dalam bentuk deposito di bank dan membeli saham di pasar modal. Return yang diperoleh dari menanm dana dalam bentuk deposito di bank adalah berupa bunga. Sedangkan return yang diperoleh dari pemilik dana yang menanamkan dananya dalam bentuk saham adalah kenaikan harga saham dan dividend. Oleh karena itu. Kenaikan harga saham secara umum tercermin dari kenaikan Indeks Harga Saham Gabungan (IHSG).

Indeks harga saham setiap hari dihitung menggunakan harga saham terakhir yang terjadi di bursa efek. Dua macam indeks yang digunakan di bursa efek adalah harga saham individual yang mencerminkan perkembangan harga suatu saham dan indeks saham gabungan yang mencerminkan perkembangan pasar secara keseluruhan. Harga saham yang dipergunakan dalam perhitungan indeks di bursa efek adalah harga saham yang terjadi di pasar regular. Jadi pengertian IHSG adalah jumlah seluruh harga saham yang ada (listed) di bursa efek (Widoatmodjo, 2006).

Jika IHSG naik, maka akan pemilik dana akan lebih tertarik menanamkan dananya dalam bentuk pembelian saham. Hal ini akan membuat simpanan deposito di bank umum 
cenderung mengalami penurunan. Sebaliknya, jika IHSG turun, maka akan mengurangi minat pemilik dana untuk menanamkan dananya dalam bentuk saham dan cenderung meningkatkan simpanan deposito masyarakat di bank umum.

\section{METODOLOGI}

\subsection{Propulasi dan Sampel}

Dalam penelitian ini yang menjadi populasi penelitian adalah bank umum di Indonesia. Sedangkan sampel dalam penelitian ini adalah data triwulanan selama periode penelitian yaitu triwulan I 2006 - triwulan II 2013, sehingga diperoleh 30 sampel data yang diaggap cukup representatif untuk menggambarkan keadaan yang sesungguhnya.

\subsection{Identifikasi dan Definisi Operasional Variabel}

Variabel-variabel yang dibahas dalam penelitian ini meliputi:

\section{Pendapatan Nasional $\left(\mathrm{X}_{1}\right)$}

Pendapatan nasional adalah nilai produksi barang dan jasa yang dihasilkan oleh suatu negara dalam satu tahun. Dalam penelitian ini, pendapatan nasional diukur dengan Produk Domestik Bruto (PDB) atau
Gross Domestic Product (GDP) harga berlaku per triwulan selama periode triwulan I 2006 - triwulan II 2013.

2. Tingkat Bunga $\left(\mathrm{X}_{2}\right)$

Tingkat bunga adalah tingkat keuntungan minimum yang disyaratkan pemodal atau tingkat keuntungan yang diharapkan pemodal dari investasi dalam bentuk simpanan. Tingkat bunga diukur dengan rata-rata tertimbang tingkat bunga deposito dari seluruh simpanan deposito pada berbagai waktu jatuh tempo yang berlaku di bank umum per triwulan selama periode penelitian, yakni triwulan I 2006 - triwulan II 2013.

3. Tingkat inflasi $\left(\mathrm{X}_{3}\right)$

Inflasi adalah kecenderungan dari harga-harga untuk naik secara umum dan terus menerus. Inflasi diukur dari kenaikan Indeks Harga Konsumen per tahun yang dinyatakan dalam persen, per triwulan selama periode penelitian (triwulan I 2006 - triwulan II 2013)

4. Nilai tukar US dollar terhadap rupiah $\left(\mathrm{X}_{4}\right)$

Nilai tukar/Kurs (exchange rate) : perbandingan nilai / harga antara 2 mata uang. Nilai tukar US dollar terhadap rupiah diukur dari kurs US dollar terhadap rupiah yang dikeluarkan oleh Bank Indonesia per 
triwulan selama periode triwulan I 2006 - triwulan II 2013.

5. Indeks Harga Saham Gabungan $\left(X_{5}\right)$ Indeks Harga Saham Gabungan adalah angka indeks yang menunjukkan perkembangan harga saham secara umum dari seluruh saham yang ditransaksikan di pasar saham Indonesia. Data IHSG diperoleh dari Bursa Efek Indonesia per triwulan selama periode triwulan I 2006 triwulan II 2013.

\section{Deposito Berjangka (Y)}

Deposito berjangka adalah simpanan yang penarikannya hanya dapat dilakukan pada waktu tertentu menurut perjanjian antara penyimpan dengan bank yang bersangkutan. Jangka waktu jatuh tempo deposito berjangka ini adalah 1 bulan, 3 bulan, 6 bulan, 12 bulan dan 24 bulan. Deposito berjangka pada lembaga perbankan di Indonesia terdiri dari deposito berjangka dalam bentuk rupiah dan valuta asing. Deposito berjangka dalam penelitian ini adalah deposito berjangka dalam bentuk rupiah pada berbagai jangka waktu jatuh tempo pada bank umum, per triwulan selama periode triwulan I 2006 - triwulan II 2013.

\subsection{Teknik Analisis}

1. Uji Simultan (Uji F)

Uji $F$ adalah uji yang digunakan untuk mengetahui signifikansi pengaruh secara simultan dari varibel bebas pendapatan nasional $\left(\mathrm{X}_{1}\right)$, tingkat bunga deposito $\left(\mathrm{X}_{2}\right)$, tingkat inflasi $\left(\mathrm{X}_{3}\right)$, nilai tukar US dollar terhadap rupiah $\left(\mathrm{X}_{4}\right)$, dan Indeks Harga Saham Gabungan $\left(\mathrm{X}_{5}\right)$ terhadap penghimpunan deposito berjangka (Y). Hal ini dilakukan dengan membandingkan nilai $\mathrm{F}$ hitung dengan F tabel.

Apabila $F_{\text {hitung }} \leq \mathrm{F}_{\text {tabel, }}$, berarti variabel-variabel bebas $\left(\mathrm{X}_{1}, \mathrm{X}_{2}, \mathrm{X}_{3}\right.$, $\left.\mathrm{X}_{4}, \mathrm{X}_{5}\right)$ secara simultan tidak berpengaruh signifikan terhadap variabel terikat (Y). Apabila $F_{\text {hitung }}>$ $F_{\text {tabel, }}$, berarti variabel-variabel bebas $\left(\mathrm{X}_{1}, \mathrm{X}_{2}, \mathrm{X}_{3}, \mathrm{X}_{4}, \mathrm{X}_{5}\right)$ secara simultan berpengaruh signifikan terhadap variabel terikat (Y). Nilai F hitung dinyatakan dengan rumus :

$$
\begin{aligned}
& \mathrm{F}_{\text {hitung }}=\frac{\mathrm{R}^{2} / \mathrm{K}}{\left(1-\mathrm{R}^{2}\right) /(\mathrm{n}-\mathrm{k}-1)} \\
& \mathrm{F}=\text { F hasil perhitungan } \\
& \mathrm{R} 2=\text { Koefisien determinasi ganda } \\
& \mathrm{k} \quad=\text { Jumlah variabel bebas } \\
& \mathrm{n} \quad=\text { Jumlah observasi }
\end{aligned}
$$


Uji F juga bisa dilakukan dengan melihat angka probabilitas kesalahan. Apabila probabilitas kesalahan (kolom sig) $\geq 0,05$, maka variabel-variabel bebas $\left(\mathrm{X}_{1}, \mathrm{X}_{2}, \mathrm{X}_{3}, \mathrm{X}_{4}, \mathrm{X}_{5}\right)$ secara simultan tidak berpengaruh signifikan terhadap variabel terikat (Y). Apabila probabilitas kesalahan (kolom sig)<0,05, maka variabel-variabel bebas $\left(\mathrm{X}_{1}, \mathrm{X}_{2}, \mathrm{X}_{3}, \mathrm{X}_{4}, \mathrm{X}_{5}\right)$ secara simultan berpengaruh signifikan terhadap variabel terikat (Y).

\section{Uji Parsial (Uji t)}

Uji t adalah uji yang digunakan untuk mengetahui signifikansi pengaruh secara parsial dari variabel bebas pendapatan nasional $\left(\mathrm{X}_{1}\right)$, tingkat bunga deposito $\left(\mathrm{X}_{2}\right)$, tingkat inflasi $\left(\mathrm{X}_{3}\right)$, nilai tukar US dollar terhadap rupiah $\left(\mathrm{X}_{4}\right)$, dan Indeks Harga Saham Gabungan $\left(\mathrm{X}_{5}\right)$ terhadap penghimpunan deposito berjangka (Y). Hal ini dilakukan dengan membandingkan nilai t hitung dengan t tabel.

Apabila $-\mathrm{t}_{\mathrm{tab}} \leq \mathrm{t}_{\text {hit }} \leq \mathrm{t}_{\mathrm{tab}}$ berarti variabel-variabel bebas $\left(\mathrm{X}_{1}, \mathrm{X}_{2}, \mathrm{X}_{3}\right.$, $\left.\mathrm{X}_{4}, \mathrm{X}_{5}\right)$ secara parsial tidak berpengaruh signifikan terhadap variabel terikat $(\mathrm{Y})$. Apabila $-\mathrm{t}_{\text {hit }}<-\mathrm{t}_{\text {tab }}$ atau $t_{\text {hit }}>\mathrm{t}_{\text {tab }}$ berarti $\mathrm{H}_{0}$ ditolak $\left(\mathrm{H}_{1}\right.$ diterima), artinya variabel-variabel bebas $\left(\mathrm{X}_{1}, \mathrm{X}_{2}, \mathrm{X}_{3}, \mathrm{X}_{4}, \mathrm{X}_{5}\right)$ secara parsial berpengaruh signifikan terhadap variabel terikat (Y). Nilai $t$ hitung dinyatakan dengan rumus:

$\mathrm{t}_{\text {hitung }}=\frac{\mathrm{b}_{\mathrm{i}}}{\mathrm{S}_{\mathrm{e}} \mathrm{b}_{\mathrm{i}}}$

$\mathrm{t}_{\text {hitung }}=\mathrm{t}$ hasil perhitungan

$b_{i} \quad=$ Koefisien regresi

$\mathrm{S}_{\mathrm{e}}=$ Standart error

Uji t juga bisa dilakukan dengan melihat angka probabilitas kesalahan. Apabila probabilitas kesalahan (kolom sig) $\geq 0,05$ maka variabel-variabel bebas $\left(\mathrm{X}_{1}, \mathrm{X}_{2}, \mathrm{X}_{3}, \mathrm{X}_{4}, \mathrm{X}_{5}\right)$ secara parsial tidak berpengaruh signifikan terhadap variabel terikat (Y). Apabila probabilitas kesalahan (kolom sig) $<0,05$ maka variabel-variabel bebas $\left(\mathrm{X}_{1}, \mathrm{X}_{2}, \mathrm{X}_{3}, \mathrm{X}_{4}, \mathrm{X}_{5}\right)$ secara parsial berpengaruh signifikan terhadap variabel terikat $(\mathrm{Y})$.

\section{PEMBAHASAN}

\subsection{Analisis Model Regresi Linier Berganda}

Regresi linier berganda merupakan suatu persamaan yang menggambarkan hubungan antara dua atau lebih variabel bebas dengan satu variabel terikat. Regresi linier berganda diterapkan pada penelitian ini untuk mengetahui apakah 
terdapat pengaruh antara pendapatan nasional, tingkat bunga deposito, tingkat inflasi, nilai tukar US dollar terhadap rupiah, dan Indeks Harga Saham Gabungan (IHSG) terhadap deposito berjangka pada bank umum di Indonesia. Dari hasil pengolahan data dengan menggunakan Program SPSS diperoleh model regresi linier berganda sebagai berikut:

$$
\begin{aligned}
Y= & -889.582,91+0,450 X_{1}+50.288,808 \\
& X_{2}-1.471,865 X_{3}+28,364 X_{4}+ \\
& 116,979 X_{5}
\end{aligned}
$$

Berdasarkan hasil perhitungan juga diketahui bahwa koefisien determinasi berganda $\left(\mathrm{R}^{2}\right)$ atau $\mathrm{R}$ Square adalah sebesar 0,988 atau 98,8\%, hal ini menunjukkan bahwa pendapatan nasional $\left(X_{1}\right)$, tingkat bunga deposito $\left(X_{2}\right)$, tingkat inflasi $\left(\mathrm{X}_{3}\right)$, nilai tukar US dollar terhadap rupiah $\left(\mathrm{X}_{4}\right)$, dan Indeks Harga Saham Gabungan $\left(\mathrm{X}_{5}\right)$ secara simultan mampu menjelaskan turun naiknya penghimpunan deposito berjangka (Y) sebesar 98,8\%, sedangkan sisanya sebesar $1,2 \%$ dipengaruhi faktor lain di luar penelitian ini.

\subsection{Pengujian Hipotesis}

\subsubsection{Uji Simultan (Uji F)}

Berdasarkan hasil perhitungan diketahui bahwa bahwa nilai signifikasi < 0,05 yaitu $0,000<0,05$, hasil perhitungan juga menunjukkan bahwa $\mathrm{F}_{\text {hitung }}>\mathrm{F}_{\text {tabel, }}$ yaitu $379,300>2,621$, hal ini menunjukkan bahwa pendapatan nasional $\left(\mathrm{X}_{1}\right)$, tingkat bunga deposito $\left(\mathrm{X}_{2}\right)$, tingkat inflasi $\left(\mathrm{X}_{3}\right)$, nilai tukar US dollar terhadap rupiah $\left(\mathrm{X}_{4}\right)$, dan Indeks Harga Saham Gabungan $\left(\mathrm{X}_{5}\right)$ secara simultan berpengaruh terhadap penghimpunan deposito berjangka (Y).

\subsubsection{Uji Parsial (Uji t)}

Nilai hitung untuk pengaruh pendapatan nasional $\left(\mathrm{X}_{1}\right)$ terhadap penghimpunan deposito berjangka (Y) adalah 12,284 dengan nilai signifikasi 0,000 (kurang dari 0,05), hal ini menunjukkan bahwa pendapatan nasional $\left(\mathrm{X}_{1}\right)$ secara parsial berpengaruh signifikan terhadap penghimpunan deposito berjangka (Y).

Nilai hitung untuk pengaruh tingkat bunga deposito $\left(\mathrm{X}_{2}\right)$ terhadap penghimpunan deposito berjangka (Y) adalah 4,877 dengan nilai signifikansi 0,000 (kurang dari 0,05), hal ini menunjukkan bahwa tingkat bunga deposito $\left(\mathrm{X}_{2}\right)$ secara parsial berpengaruh 
signifikan terhadap penghimpunan deposito berjangka (Y).

Nilai hitung untuk pengaruh tingkat inflasi $\left(\mathrm{X}_{3}\right)$ terhadap penghimpunan deposito berjangka (Y) adalah $-0,634$ dengan nilai signifikasi 0,532 (lebih dari 0,05), hal ini menunjukkan bahwa tingkat inflasi $\left(\mathrm{X}_{3}\right)$ secara parsial tidak berpengaruh signifikan terhadap penghimpunan deposito berjangka (Y).

Nilai hitung untuk pengaruh nilai tukar US Dollar terhadap Rupiah $\left(\mathrm{X}_{4}\right)$ terhadap penghimpunan deposito berjangka (Y) adalah 2,444 dengan nilai signifikasi 0,022 (kurang dari 0,05), hal ini menunjukkan bahwa nilai tukar US dollar terhadap rupiah $\left(\mathrm{X}_{4}\right)$ secara parsial berpengaruh signifikan terhadap penghimpunan deposito berjangka (Y).

Nilai hitung untuk pengaruh Indeks Harga Saham Gabungan $\left(\mathrm{X}_{5}\right)$ terhadap penghimpunan deposito berjangka (Y) adalah sebesar 6,000 dengan nilai signifikasi 0,000 (kurang dari 0,05), hal ini menunjukkan bahwa Indeks Harga Saham Gabungan $\left(\mathrm{X}_{5}\right)$ secara parsial berpengaruh signifikan terhadap penghimpunan deposito berjangka (Y).

\subsection{Pengaruh Pendapatan Nasional terhadap Penghimpunan Deposito Berjangka}

Berdasarkan hasil penelitian analisis regresi berganda menunjukkan koefisien regresi pendapatan nasional sebesar 0,450 dengan nilai toleransi sebesar $0,000(0,000<0,05)$ sehingga $\mathrm{H}_{0}$ ditolak. Hal ini berarti bahwa pendapatan nasional berpengaruh positif dan signifikan terhadap penghimpunan deposito berjangka pada bank umum di Indonesia.

Adanya pengaruh yang signifikan ini sesuai dengan teori "absolute income hypothesis" dari pemikiran Keynes yang menjelaskan tentang hubungan antara pendapatan dengan konsumsi dan simpanan. Menurut teori ini, oleh karena simpanan merupakan bagian pendapatan yang tidak dikonsumsikan, maka simpanan (saving) merupakan fungsi dari pendapatan (Fry, 2006:5). Berdasarkan teori ini, tidak semua dari pendapatan yang diterima seseorang akan digunakan untuk konsumsi, melainkan sebagian akan disimpan sebagai simpanan (saving). (Boediono, 2005 : 37). Lebih jauh dikatakan bahwa perilaku konsumsi dan menyimpan dari seseorang sangat dipengaruhi oleh pendapatannya. Suatu kenaikan dalam pendapatan akan meningkatkan konsumsi dan simpanan, tetapi tidak sebesar kenaikan dari tingkat pendapatannya. 


\subsection{Pengaruh Tingkat Bunga} Terhadap Penghimpunan Deposito Berjangka

Berdasarkan hasil penelitian analisis regresi berganda menunjukkan koefisien regresi tingkat bunga deposito sebesar 50.288,808 dengan nilai toleransi sebesar $0,000(0,000<0,05)$ sehingga $\mathrm{H} 0$ ditolak. Hal ini berarti bahwa tingkat bunga deposito berpengaruh positif dan signifikan terhadap penghimpunan deposito berjangka pada bank umum di Indonesia.

Adanya pengaruh yang signifikan ini sesuai dengan teori loanable funds, yaitu merupakan sisi supply dari loanable funds. Sisi supply dari loanable funds menerangkan hubungan antara tingkat bunga dan simpanan, di mana hubungan kedua variabel tersebut bersifat positif. Semakin besar tingkat bunga akan meningkatkan kesediaan masyarakat untuk menyimpan dananya pada lembaga perbankan, sehingga jumlah simpanan masyarakat pada lembaga perbankan akan naik. Menurut Rose, et. al. (2007:69), dengan naiknya tingkat bunga simpanan, masyarakat akan menunda penggunaan kelebihan dananya untuk konsumsi sekarang (di luar kebutuhan hidup sehari-hari) dengan harapan akan memperoleh pendapatan untuk konsumsi yang lebih banyak di masa mendatang, dengan begitu maka masyarakat akan menginvestasikan kelebihan dana yang dipunyainya pada bank-bank yang ada. Hal ini terjadi karena masyarakat akan memperoleh pendapatan yang lebih banyak dengan naiknya tingkat bunga tersebut.

\subsection{Pengaruh Inflasi terhadap}

\section{Penghimpunan Deposito Berjangka}

Berdasarkan hasil penelitian analisis regresi berganda menunjukkan koefisien regresi tingkat inflasi sebesar 1.471,865 dengan nilai toleransi sebesar $0,532(0,532>0,05)$ sehingga $\mathrm{H}_{0}$ diterima. Hal ini berarti bahwa tingkat inflasi berpengaruh negatif dan tidak signifikan terhadap penghimpunan deposito berjangka pada bank umum di Indonesia.

Tidak adanya pengaruh yang signifikan ini menggambarkan bahwa di satu sisi terjadi inflasi dan bersamaan dengan itu masyarakat cenderung mengurangi simpanannya di bank dan digunakan untuk melakukan pembelian barang dan jasa atau diinvestasikan dalam bentuk lain. Hal ini karena inflasi yang tinggi di Indonesia terjadi bersamaan 
dengan menjelang lebaran, menjelang tahun baru, atau kenaikan harga bahan bakar minyak, di mana hal tersebut justru memicu masyarakat untuk berbelanja sehingga mengurangi simpanannya di bank.

\subsection{Pengaruh Nilai Tukar terhadap Penghimpunan Deposito Berjangka}

Berdasarkan hasil penelitian analisis regresi berganda menunjukkan koefisien regresi nilai tukar US dollar terhadap rupiah sebesar 28,364 dengan nilai toleransi sebesar $0,022(0,022<0,05)$ sehingga $\mathrm{H}_{0}$ ditolak. Hal ini berarti bahwa nilai tukar US dollar terhadap rupiah berpengaruh positif dan signifikan terhadap penghimpunan deposito berjangka pada bank umum di Indonesia.

Adanya pengaruh yang signifikan ini disebabkan karena besarnya return yang diterima seorang penabung juga dipengaruhi oleh nilai tukar US Dollar terhadap rupiah. Jika nilai tukar US Dollar terhadap rupiah naik, maka simpanan deposito rupiah cenderung merugikan penabung (deposan), karena akan mengurangi return yang diterima oleh penabung, sehingga hal ini akan membuat penabung mengalihkan simpanan depositonya dari rupiah ke dalam deposito US dollar, sehingga jumlah simpanan deposito rupiah akan cenderung menurun. Sebaliknya, jika nilai tukar US Dollar terhadap rupiah turun, maka penabung akan mengalihkan simpanan depositonya dari bentuk US Dollar menjadi deposito rupiah, sehingga jumlah simpanan deposito rupiah masyarakat di bank umum akan naik.

\subsection{Pengaruh Indeks Harga Saham Gabungan terhadap Penghimpunan Deposito Berjangka}

Berdasarkan hasil penelitian analisis regresi berganda menunjukkan koefisien regresi Indeks Harga Saham Gabungan sebesar 116,979 dengan nilai toleransi sebesar $0,000 \quad(0,000<0,05)$ sehingga $\mathrm{H}_{0}$ ditolak. Hal ini berarti bahwa Indeks Harga Saham Gabungan berpengaruh positif dan signifikan terhadap penghimpunan deposito berjangka pada bank umum di Indonesia.

Adanya pengaruh yang signifikan ini disebabkan karena berinvestasi pada saham adalah salah satu bentuk investasi selain menyimpan deposito di bank. Memperbanyak variasi dalam berinvestasi (portofolio investasi) merupakan salah satu cara untuk mengurangi risiko. Selain menanamkan dana dalam bentuk simpanan deposito di bank, seorang pemilik dana dapat 
mencari alternatif lain dalam menanamkan dananya yaitu dalam bentuk pembelian saham. Suatu saat, pemilik dana akan dihadapkan pada pilihan investasi mana yang lebih menguntungkan dalam arti memberikan return yang lebih besar antara menanam dana dalam bentuk deposito di bank dan membeli saham di pasar modal, atau mana yang paling kecil risiko di antara keduanya ketika kondisi perekonomian tidak stabil.

Jika suku bunga meningkat, maka pemilik dana cenderung menyimpan investasinya dalam bentuk tabungan, sebaliknya apabila suku bunga menurun, maka pemilik dana cenderung menginvestasikan pada sektor riil. Jika IHSG naik, maka akan pemilik dana akan lebih tertarik menanamkan dananya dalam bentuk pembelian saham. Hal ini akan membuat simpanan deposito di bank umum cenderung mengalami penurunan. Sebaliknya, jika IHSG turun, maka akan mengurangi minat pemilik dana untuk menanamkan dananya dalam bentuk saham dan cenderung meningkatkan simpanan deposito masyarakat di bank umum.

\section{KESIMPULAN DAN SARAN}

\subsection{Kesimpulan}

Berdasarkan hasil penelitian yang telah dilakukan dapat diambil simpulan sebagai berikut:

1. Pendapatan nasional, tingkat bunga deposito, tingkat inflasi, nilai tukar US dollar terhadap rupiah, dan Indeks Harga Saham Gabungan secara simultan berpengaruh signifikan terhadap penghimpunan deposito berjangka pada bank umum di Indonesia.

2. Pendapatan nasional, tingkat bunga deposito, nilai tukar US dollar terhadap rupiah, dan Indeks Harga Saham Gabungan secara parsial berpengaruh signifikan terhadap penghimpunan deposito berjangka pada bank umum di Indonesia. Namun tingkat inflasi secara parsial tidak berpengaruh signifikan terhadap penghimpunan deposito berjangka pada bank umum di Indonesia.

3. Dari kelima faktor tersebut, pendapatan nasional memiliki pengaruh dominan terhadap penghimpunan deposito berjangka pada bank umum di Indonesia.

\subsection{Saran}

1. Penelitian lebih lanjut disarankan 
untuk menambah jumlah sampel penelitian dan menambah tahun pengamatan.

2. Penelitian selanjutnya dapat menambahkan faktor-faktor lain yang dapat mempengaruhi besarnya penghimpunan deposito berjangka.

3. Penelitian selanjutnya disarankan dapat memperluas objek penelitian, tidak hanya terbatas pada bank umum di Indonesia sehingga hasil penelitian bisa digeneralisasikan.

\section{DAFTAR PUSTAKA}

Anoraga, Pandji Danpakarti, Piji, 2008, Pelanggar Pasar Modal, Edisi Revisi, Cetakan Ketiga, Penerbit PT. Rineka Cipta, Jakarta.

Arsyad, Lincolin, 2007, Ekonomi Pembangunan, Bagian Penerbitan STIE YKPN, Yogyakarta.

Boediono, 2005, Ekonomi Makro, Seri Sinopsis Pengantar Ilmu Ekonomi No. 2, BPFE, Yogyakarta. -, 2006, Ekonomi Moneter, Seri Sinopsis Pengantar Ilmu Ekonomi No. 5, BPFE, Yogyakarta.
Bolten, S.E. \& Weigand, R.A., 2007, the Generation of Stock market Cycles, the Financial Review Journal, Vol.54.

Fry, Maxwell J., 2006, “Monetary Policy and Domestic Saving in Developing ESCAP Countries", Economic Bulletin for Asia and Pasific, Vol. XXIX, No. 1, June.

Goeltom, Miranda S., 2006, Perubahan Struktural Keuangan di Indonesia : Visi dan Tantangan, Seminar Mencari Paradigma Baru Pembangunan Indonesia, Jakarta, 13 Agustus.

Gujarati, Damodar, 2008, Ekonometrika Dasar, Terjemahan, Penerbit Erlangga, Jakarta.

Hady, Hamdy, 2007, Ekonomi Internasional, Teori dan Kebijakan Keuangan Internasional, Ghalia Indonesia, Jakarta.

Horvitz, Paul M., 2005, Monetary Policy and The Financial System, Prentice-Hall Inc, Englewood Cliffs, New Jersey. 
Jogiyanto. 2007. "Teori Portofolio dan Analisis Investasi”, Yogyakarta: BPFE.

Johnson, Frank D., and Johnson, Richard D., 2008, Commercial Bank Management, The Dryden Press, New York.

Jusuf, Jopie, 2007, Panduan Dasar Untuk Account Officer, Intermedia, Jakarta.

Kothari, SP. 2009. "Capital Market Research in Accounting”. Journal of Accounting \& Economics, 39.

Kusdiyanto, 2008, Analisis Pengaruh Beberapa Faktor Terhadap Deposito dan Kredit Bank-Bank Umum Devisa di Indonesia, Tesis Pada Program Studi Ilmu Manajemen, Program

Pascasarjana Universitas

Airlangga, Surabaya.

Landreth, Harry, 2006, History of Economic Theory, Terjemahan, LP3-UI, Jakarta.
Luckett, Dudley G., 2010, Money and Banking, Mc. Graw-hill Company, New York.

Miskhin, Frederic S., 2008, The Economics of Money, Banking, and Financial Markets, Harper Collins Publisher, New York.

Nopirin, 2007, Ekonomi Moneter, Buku II, BPFE, Yogyakarta.

Reksoprayitno, Soedijono, 2006, Prinsip-Prinsip Dasar Manajemen Bank Umum, BPFE, Yogyakarta.

Rose, Peter S., et al., 2007, Financial Institution Understanding and Financial Services, IRWIN, Boston.

Samuelson, Paul A. dan Nordhaus, William D., 2008, Ekonomi, Terjemahan, Penerbit Erlangga, Jakarta.

Siamat, Dahlan, 2009, Manajemen Bank Umum, Intermedia, Jakarta.

Sinungan, M., 2008, Manajemen Dana Bank, Grafiti, Jakarta. 
Sumaryati, Maria Margaretha, 2006, Analisis Efisiensi Pengelolaan Dana Perbankan di Indonesia, Tesis, UGM, Yogyakarta.

Suwito, Sugito, 2006, Sumbangan Komoditi Pangan Sebagai Penyebab Inflasi di Indonesia, Seminar Sehari Kerjasama PERHEPI dan ISEI Cabang Jakarta, 18 Januari.

UTun Wai, 1972, Financial Intermediaries and National Savings in Developing Countries, Praeger Publisher, New york.

Weston, J. Fred dan Copeland, 2007, Manajemen Keuangan, Jilid I, Terjemahan, Bina Rupa Aksara, Jakarta.

Widoatmodjo S., 2006, Cara Sehat Investasi di Pasar Modal, Penerbit Jurnalindo Aksara Grafika, Jakarta.

Supranto, 2008, Statistik Pasar Modal, Penerbit Rineka Cipta, Jakarta 